\title{
LEADERSHIP ON EMPLOYEES' PERFORMANCE TERANG UTAMA ABADI LTD. THROUGH SENSE OF ACHIEVEMENT
}

\author{
Davy Christian \\ davychristian95@gmail.com \\ Tina Melinda \\ Faculty of Business and Management, Ciputra University \\ Citraland CBD Boulevard, Surabaya 60219, Indonesia
}

received: 24/5/18; revised: 17/6/18; published: 31/12/18

\begin{abstract}
Achievement earned by the company is inseparable from the employees' performance. There are several factors affecting their performance. Two of them are leadership and motivation. The study aims to examine the influence of leadership on the sense of the achievement of the employees of Terang Utama Abadi (TUA) Ltd., the influence of leadership on the performance of the employees at TUA Ltd., the influence of the sense of achievement on the performance of employees at TUA Ltd., and the sense of achievement as an intervening variable on employee at TUA Ltd.. The respondents of this study were fifty-eight employees at TUA Ltd. This study was a quantitative research with structural equation modelling partial least square method. Questionnaires were used to collect the primary data. This study found that leadership and sense of achievement has positive influence on the employees' performance. Meanwhile, the sense of achievement served as an intervening variable.
\end{abstract}

Keywords: leadership; sense of achievement; motivation; achievement motivation; employee's performance

\section{INTRODUCTION}

By 2015, Indonesia's GDP growth reached 4.87\%. In 2016, Indonesia's GDP growth was about 5.01\%, and was projected to continue to increase in 2017 up to $5.5 \%$ (Badan Pusat Statistik, 2016). The increase in GDP can not be separated from the increase in sales from various industry sectors in Indonesia. One of the industries supporting Indonesia's economic growth is the automotive industry. Throughout the year 2016, sales of four-wheeled vehicles or more in Indonesia reached 1,062,729 units. The sales figure increased by 49,438 units from 2015 (Gaikindo, 2017). This condition shows the automotive industry in Indonesia continues to grow in a positive direction. Based on this fact, Terang Utama Abadi (TUA) Ltd. as a company engaged in the distribution and sales of automotive take the opportunity to focus on developing its business. TUA Ltd. currently holds the distribution and sales license of TATA Motors brand vehicles in East Java. Due to its outstanding performance, TUA Ltd. get various awards at national scale from TMDI Ltd.

Various achievements achieved by TUA Ltd. cannot be separated from the outstanding performance of the employees. Their performance is influenced by several factors. The four factors affecting the employee's performance such as organization culture, motivation, leadership, and work environment (Syafei, Fahmi, \& Hubeis, 2016). Previous survey has been conducted towards 30 employees at TUA Ltd., focusing on factors affecting their performance. Based on the results of this pre-survey, leadership and motivation factors has higher average response than the other two factors, organization culture and work environment. Organization culture and work environment at TUA Ltd. were not significantly affecting the performace due to TUA Ltd's short business time span. This company has just been in operation for only two years. TUA Ltd. is about to start building its organizational culture and favourable work environment. Regarding leadership and motivation, TUA Ltd. sells automotive products with TATA brand. In fact, these products are relatively very new in Indonesian automotive industry. For employees, selling TATA Motors brand vehicles is much more difficult than selling competing brand vehicles already known by the majority of Indonesians. This makes the role of the company leader important to lead the employees. In addition, selling TATA Motors is more difficult for the employees need to have motivation and achievement. These serve rationales for the 
researcher to conduct research about factors affecting the performance of TUA Ltd. These factors include the leadership applied by leaders at TUA Ltd. and internal and external motivation. This is also supported by previous research conducted by (Lina, 2014). She stated that leadership has a significant effect on employees' performance; meanwhile, organizational cultures has no significant effect on employees' performance. (Tampi, 2014) stated leadership and motivation has a positive and significant influence on employees' performance. According to (Marpaung, 2014), leadership has a strong and significant influence on employee's performance. Motivation has a strong influence on performance up to $57.14 \%$ because of sense of achievement (Siregar, 2016).

Leadership is defined as a way people manage to influence, coordinate, and direct the activities of others in order to achieve group goals or organizational goals (Nur, 2017). (Rewah, 2015) argues that leadership is the behavior of an individual who leads a group's activities to achieve common goals. Sense of achievement is something that motivates individuals to face challenges in the interest of achieving success (Mehta \& Gupta, 2014). It directs individuals to go through difficulties by focusing on achievable objectives, striving to produce the best performance, calculating risks, confronting uncertainty and tolerating ambiguity, seeking creative solutions to solve problems, and assuming personal responsibility for consequences/behaviour (Deshpandé, Grinstein, Kim, \& Ofek, 2013). Ma'ruf Abdullah (2014) suggests that performance is a description of the level of achievement of the implementation of an activity or policy program in realizing organizational goals, objectives, vision and mission as outlined through strategic planning of an organization.

Based on the background of the study, the researchers are conducting this research. This study is intended to examine the influence of leadership on the sense of achievement employees at TUA Ltd., the influence of leadership on the performance of employees at TUA Ltd., examine the influence of sense of achievement on the performance of employees at TUA Ltd., to test the sense of achievement as an intervening variable on the employees at TUA Ltd.

\section{METHODS}

The type of research used in this study was quantitative research with non-probability sampling used as a sampling method. This research used Partial Least Square (PLS) method known as one of method in analyzing Structural Equation Modeling (SEM). The research was conducted from April to October 2017.

Seventy-one employees in four branches such as Tulungagung, Kediri, Blitar, and Jombang became the population of the study. The non-probability purposive sampling method was employed to draw the samples of the study. According (Sujarweni, 2014), purposive sampling technique has to acquire certain criteria when drawing samples. In this study, the criteria were the employees who worked in TUA Ltd. with positions other than directors, branch managers, office boys, drivers, and securities. Having previously determined by the researchers, these criteria were intended to focus on role of leadership as shown by the directors and branch managers when managing their employees. In addition, the sense of employees' achievement at sale unit, service units, and spare part unit also became the focus of the study. Employees who did not meet the criteria included a director, two branch managers, two drivers, three office boys, and five securities. The respondents who meets the criteria are 58 employees. The questionnaires were distributed to 58 respondents from four dealer branches of TUA Ltd.

The variables in this study are employee's performance, leadership, and sense of achievement. Each variable have its own indicators which are quantity of work, quality of work, punctuality, presence, and ability of coorperation (employee's performance) ; telling, selling, participating, and delegating (leadership); consistently working, acceptance of setback, coadaption with team, belief of success, feedback of work, career growth opportunity, swiftness of work, difficulty level of assigned task, preference office work, tolerance of mistake, out of office work, salary satisfaction, reward, incentive target alliance (sense of achievement).

\section{RESULTS}

The Initial stages of data processing using SEMPLS was to move the entire answer questionnaire into Microsoft Excel program before saving the file with the format .csv (comma delimited). The next step was to draw a research model with the SmartPLS 3.0 program. Testing the validity of the outer model could be seen in the loading factor. The loading factor value of all the indicators X1, X2, and Y in Figure 1 met the critical value greater than 0.5 .

Table 1 shows that the AVE values of the three latent variables in this study were eligible for they were at more than 0.5. Cronbach's Alpha value. Leadership, sense of achievement, and employee's performance has met the requirement since they were greater than the critical value 0.6. The Composite Reliability value for each variable in this study also met the requirements for they were greater than the critical value 0.7.

Table 2 shows the R-Square Value. The R-Square value for the sense of achievement variable was 0.287 . This meant the percentage of the diversity of the sense of achievement variables was contributed by the $28.7 \%$ of the leadership variable; meanwhile, the remaining $71.3 \%$ was explained by other variables. In other words, $28.7 \%$ of leadership variable influenced the sense of achievement variable. The R-Square value for the 
employee's performance variable was 0.543 , meaning means that the employee's performance was influenced by the sense of achievement of $54.3 \%$. Meanwhile, the remaining $45.7 \%$ was influenced by other variables beyond the sense of achievement.

Table 3 showed the value of Path Coefficients and T-Statistics. The path coefficient value of leadership influencing the sense of achievement variable was 0.536 with t-statistics of 5.497. The value of t-statistics was greater than the value of t-table 1.96. This shows that there was a significant influence between leadership and sense of achievement. This finding showed that the first hypothesis of this research was proved to be true. The coefficients path value of leadership influencing employee's performance was 0.308 with t-statistics of 2.011. The value of t-statistics was greater than the value of t-table 1.96. This showed that there was a significant influence between leadership and employee's performance. This finding showed that the second hypothesis of this research was proved to be true. The value of the path coefficients influencing the sense of achievement employee's performance was equal to 0.525 with t-statistics of 3.612. The value of t-statistics was greater than the value of t-table 1.96. This finding showed that there was a significant influence between the sense of achievement and employee's performance. This finding showed that the third hypothesis of this study was also proved to be true.

\section{DISCUSSIONS}

Table 3 shows that the value of t-statistics leadership (X1) to the sense of achievement (X2) was 5.497. While such a value greater than the value of $t$-table was 1.96 , this finding proved that leadership (X1) has a significant influence on the sense of achievement (X2) at TUA Ltd. This finding was in line with the previous research conducted by (Indra, 2015). He mentioned that leadership significantly influenced the sense of achievement. The leadership applied by the leaders was higher than the employee's motivation. It was because the respondents believed that the leadership has provided good examples to their employees. Hence, they became loyal to the organization, be able to motivate employees to continue improving their work. These leaders were exemplary figures since they were capable of encouraging employees to be more creative, conveying ideas to employees in completing the work, having a good attention to employees and giving awards to employees who made achievement. In principle, leaders with good leadership skills would motivate employees to do better jobs. In so doing, their attitude could increase the employees' confidence or selfconfidence that would later affect the improvement of their performance (Indra, 2015). This study found that the leadership at TUA Ltd. was good enough in nearly all areas. Information about what to do has to be delivered by the leaders to the employees when the latter began their work at the first time. However, there was no clear information about what the employees has to do.

The ratio of between employee and employee was different. In fact, the leaders at TUA Ltd. has a lot of responsibilities not only foscusing on employees, but also on other internal and external sectors of the company. Delegating tasks to the employees as given by the leaders at TUA Ltd. was done tentatively. Delegates were related to the tasks commonly done by the leader. However, because the leaders has important agenda, they would assign the employees to do that. In fact, delegating the tasks and and information to the employees were already properly done. To many employees, the ideas the leaders gave was very easy to do. However, it was easy to do though by other employees working at different levels.

Table 3 showed that the value of t-statistics leadership (X1) on employee's performance (Y) was 2.011. The value greater than the value of $t$-table was 1.96. This finding proved that leadership (X1) has a significant effect on the employees' performance (Y) at TUA Ltd. This was in line with previous research conducted by (Tampi, 2014). He mentioned that the leadership has a positive influence on the performance of employees. Good leadership was one of the factors improving the performance of employees. Leadership served as the backbone of organizational development in encouraging, and affecting good morale to subordinates. (Putra, 2014) explained that the readiness and maturity of employees in doing their work were derived from the level of direction and guidance and emotional support provided by provided by leaders. Establishment of readiness and maturity in employees led employees to gain their best performance. The strong sense of achievement shown by employees at TUA Ltd. was those working at the sales department. They were too careful at making failures so that they felt uneasy to accept the failure such as not achieving sales targets. This view constantly made employees demotivated, inferior or unconfident. Low acceptance of setback value in employees of TUA Ltd. was common among new employees. At the beginning, the employees has been explained about what target to achieve and what the consequences to get when they failded. There were two types of employees at TUA Ltd: employees who were eager to succeed although they failded and employees who easlily gave up by submitting the resigning letters and moving to other brand dealers.

The difficulty level of assigned task was related to job targets assigned to each employee. The target of each employee was set according to company standard. However, TATA Motors was a brand new automotive brand that made selling TATA Motors product more difficult than selling competitor brand product. Belief of success in each employee was inseparable from 
the motivation given by the leaders at TUA Ltd. In short, in addition to good work team formed within the company, mutual support was also important to create favourable working atmosphere.

Table 3 showed that the value of $t$-statistics sense of achievement (X2) on employee's performance (Y) was 3,612 . The value greater than the value of $t$-table was 1.96. This finding proved that the sense of achievement (X2) has a significant effect on employee's performance (Y) at TUA Ltd. This was in line with previous research conducted by (Andreani, 2015). They explained that the sense of achievement / achievement motivation has a positive and significant influence on employee's performance. If a company's top management focused on the motivation of their employees, the motivation for achievement would lead to positive employee's performance improvement (Zameer, Alireza, Nisar, \& Amir, 2014). According to (Siregar, 2016), the sense of achievement has a positive and considerable relationship to performance. The sense of achievement provided an encouragement to the individual so that they could overcome all challenges and obstacles. The employees who has this motivation were eager to grow and go through the ladder of success, to the highest ladder. Facts found that the performance of employees at TUA Ltd. was good although they were still working for two years and the sales figures were still not stable. However, their achievement made them granted with some awards as the best TATA Motors dealer in Indonesia. This finding showed how the performance of employees of TUA Ltd. was excellent for they could give a positive impact on the company's performance. The number of jobs and quality criteria charged to each employee were in accordance with the criteria set by the companies. In fact, the employees were committed to those task criteria. Nevertheless, many sales cases encountered several problems related to credit financing. This condition affected the performance of employees at the company. Until now leasing banks working with TATA Motors was still limited. It affected the package of credit financing programs provided to customers. Customers tended to choose a competitor's product because they got a much lower down payment. Moreover, a choice of leasing banks according to customer's wishes varied. The process of examination conducted by the leasing bank also took a long time (about 14 days). This condition affected the timeliness of employees and kept them from achieving the sale target. When the inspection process was completed and accepted, employees could do closing and reach the target. In terms of punctuality of morning attendance, there were still many employees coming late. In terms of ability of cooperation between employees, the employees has shown good performance. It was because of good work team with the sense of e kinship. Regarding the attendance, a lot of employees weabsent or too late to attend attendance every day working hours.
According to (Zhao, Lynch, \& Chen, 2010), when the value was multiplied by significant $b$ and significant $c$ value, and multiplication value between $a, b$, and $\mathrm{c}$ was positive. The $\mathrm{X} 2$ variable in the model was a complementary intervening/mediation variable in the study. After going through the process of bootstrapping, calculation, and checking the above conditions came to the finding: the sense of achievement (X2) served as an intervening variable between leadership variables (X1) on employee's performance (Y). This was in line with previous research conducted by (Indra, 2015) who explained that the style of leadership (leadership) transformational gave indirect impacts on employee's performance through work motivation. Transformational leadership in principle motivated employees to do better. Short speaking, leadership increased the confidence or self-confidence of employees that would affect the improvement of employee's performance. This was because the achievement motivation grew within the employees that strengthened performance in order to obtain the achievement.

\section{CONCLUSIONS}

Based on the results of research and discussion of leadership influence on employee's performance TUA Ltd. through a sense of achievement as an intervening variable, it can be concluded that: (1) Leadership has a positive effect on the sense of achievement. There are four leadership indicators that are telling, selling, participating, and delegating. These four variables reflect leadership variables. Sense of achievement can be improved by improvements in the leadership of the company leadership. (2) Leadership positively affects the performance of employees of TUA Ltd. There are four indicators that reflect leadership that is telling, selling, participating, and delegating. Leadership run by the head of TUA Ltd. can improve the performance of employees of TUA Ltd. of the number of jobs, job quality, punctuality, attendance, and collaborative skills. Leadership has the greatest impact on employee's performance. Therefore, if leadership increases then employee's performance will also increase more significantly than the increase in the sense of achievement. (3) Sense of achievement has a positive effect on the performance of employees of TUA Ltd. There are twelve indicators that reflect the sense of achievement: consistently working, acceptance of setback, coadaption with team, belief of success, feedback of work, career growth opportunity, swiftness of work, difficulty level of assigned task, preference office work, tolerance of mistake, out of office work, and compensation. Increasing the sense of achievement of employees can improve the performance of employees of TUA Ltd. of the number of jobs, job quality, punctuality, attendance, and collaborative skills. (4) Sense of achievement is an intervening variable 
between leadership and employee's performance of TUA Ltd. Sense of achievement is an intermediate variable between leadership variables and employee's performance variables. Sense of achievement has a positive effect on employee's performance. The intervening variable type in this model is complementary mediation.

\section{REFERENCES}

Andreani, T. W. Dan F. 2015. Pengaruh Motivasi dan Kompensasi terhadap Kinerja Karyawan pada PT Sinar Jaya Abadi Bersama. AGORA.

Badan Pusat Statistik. 2016. Produk Domestik Bruto Indonesia. Retrieved from http://bps.go.id/

Deshpandé, R., Grinstein, A., Kim, S. H., \& Ofek, E. 2013. Achievement Motivation, Strategic Orientations and Business Performance in Entrepreneurial Firms: How Different are Japanese and American Founders? International Marketing Review. Https:// Doi.Org/10.1108/02651331311321981

Gaikindo. 2017. Data Penjualan Kendaraan Roda Empat atau Lebih Berdasarkan Kategori di Indonesia. Retrieved from http://gaikindo.or.id/

Indra, K. 2015. Pengaruh Gaya Kepemimpinan Transformasional terhadap Kinerja Karyawan dengan Motivasi Kerja sebagai Variabel Intervening (Studi pada Karyawan Bank Jatim Cabang Malang). Jurnal Administrasi Bisnis.

Lina, D. 2014. Analisis Pengaruh Kepemimpinan dan Budaya Organisasi terhadap Kinerja Pegawai dengan Reward sebagai Variabel Moderating. Jurnal Riset Akuntansi dan Bisnis.

Marpaung, M. 2014. Pengaruh Kepemimpinan dan Team Work terhadap Kinerja Karyawan di Koperasi Sekjen Kemdikbud Senayan Jakarta. Jurnal Ilmiah WIDYA.

Mehta, C., \& Gupta, P. 2014. Corporate Entrepreneurship: A Study on Entrepreneurial Personality of Employees. Global Journal of Finance and Management.

Nur, I. A. 2017. Pengaruh Kepemimpinan Transaksional terhadap Motivasi Intrinsik, Work Engagement dan Kinerja Karyawan. Business Studies. https://
doi.org/10.1002/Anie.201703841

Prof. Dr. H. M. Ma'ruf Abdullah, S. M. 2014. Manajemen dan Evaluasi Kinerja Karyawan. Perpustakaan Nasional RI: Katalog Dalam Terbitan (KDT) Manajemen dan Evaluasi Kinerja Karyawan. $X v i+228$ Halaman, 15.5 X $23 \mathrm{Cm}$ Ii. https://doi. org/10.1016/S0187-6236(13)71071-3

Putra, S. B. 2014. Pengaruh Gaya Kepemimpinan Situasional dan Lingkungan Kerja terhadap Kinerja Karyawan dengan Motivasi Kerja sebagai Variabel Intervening (Studi Pada PT Bank OCBC NISP Tbk. KCP Bekasi). Universitas Diponegoro.

Rewah, D. R. 2015. Hubungan Fungsi Kepemimpinan Kepala Desa dengan Efektivitas Kerja Aparatur Pemerintah Desa (Suatu Studi di Kecamatan Langowan Utara Kabupaten Minahasa). Jurnal Administrasi Publik.

Siregar, A. N. 2016. Hubungan antara Motivasi dan Budaya Kerja dengan Kinerja Penyuluh Pertanian di Kabupaten Subang, Provinsi Jawa Barat. Jurnal Penyuluhan Pertanian.

Sujarweni, V. W. 2014. Metodologi Penelitian Lengkap, Praktis, dan Mudah Dipahami. Yogyakarta. Pustaka Baru Press.

Syafei, M., Fahmi, I., \& Hubeis, A. V. S. 2016. FaktorFaktor yang Memengaruhi Kinerja Karyawan PT Pul Logistics Indonesia. Jurnal Aplikasi Bisnis dan Manajemen. https://doi.org/10.17358/ JABM.2.3.217

Tampi, B. J. 2014. Pengaruh Gaya Kepemimpinan dan Motivasi terhadap Kinerja Karyawan Pada PT. Bank Negara Indonesia,Tbk (Regional Sales Manado). Acta Diurna.

Zameer, H., Alireza, S., Nisar, W., \& Amir, M. 2014. The Impact of The Motivation on the Employee Performance in Beverage Industry of Pakistan. International Journal Of Academic Research In Accounting, Finance And Management Sciences. https://doi.org/10.6007/IJARAFMS/V4-I1/630

Zhao, X., Lynch, J. G., \& Chen, Q. 2010. Reconsidering Baron and Kenny: Myths and Truths about Mediation Analysis. Journal of Consumer Research. https:// doi.org/10.1086/651257 


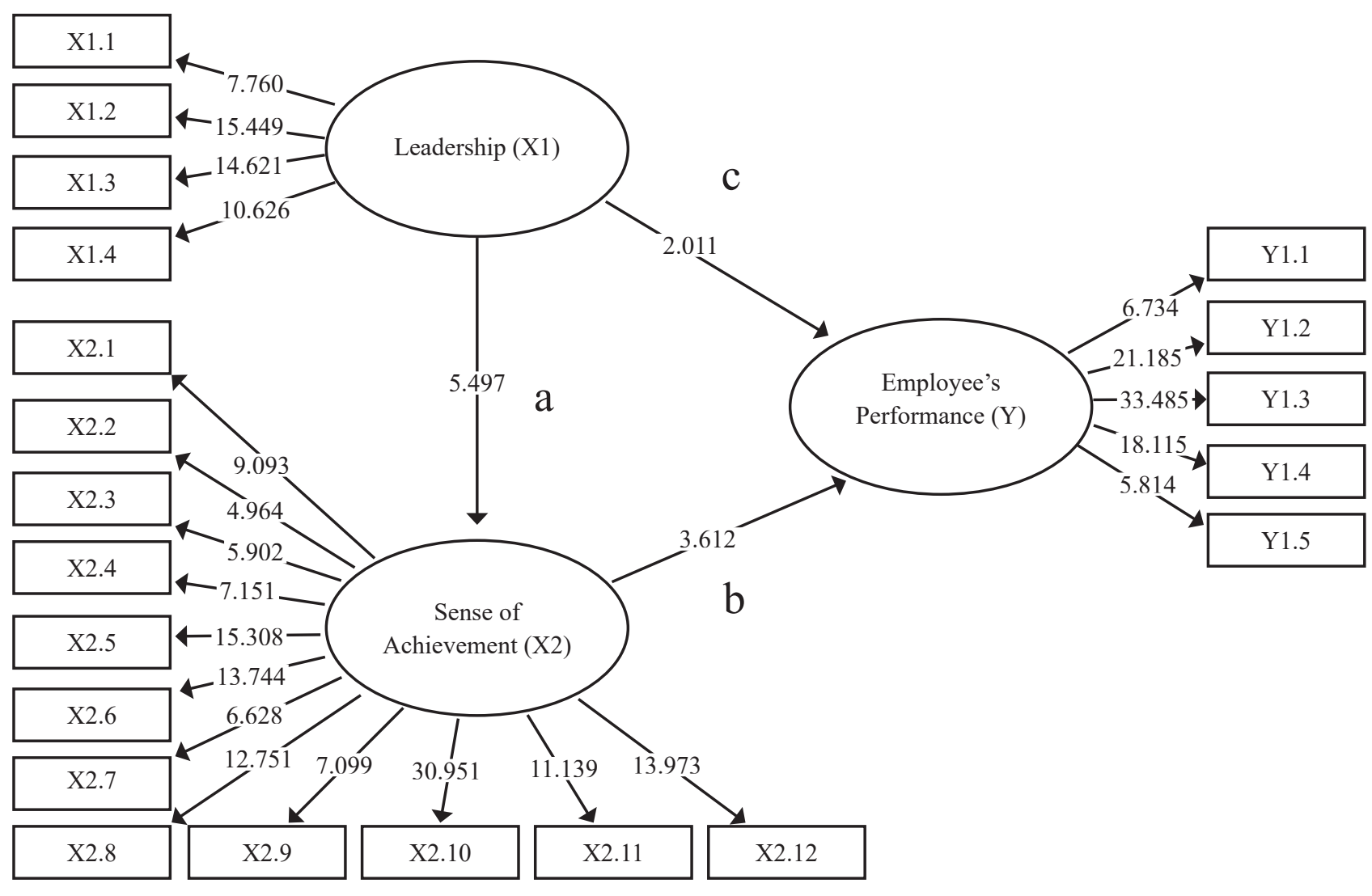

Figure 1. Bootstraping

Table 1. AVE, Cronbach's Alpha, and Composite Reliability Value

\begin{tabular}{lrrr}
\hline & $\begin{array}{c}\text { Average } \\
\text { Variance } \\
\text { Extracted }\end{array}$ & $\begin{array}{c}\text { Cronbach's } \\
\text { Alpha }\end{array}$ & $\begin{array}{c}\text { Composite } \\
\text { Reliability }\end{array}$ \\
\hline Leadership (X1) & 0.579 & 0.757 & 0.846 \\
Sense of Achievement (X2) & 0.520 & 0.914 & 0.927 \\
Employee's Performance(Y) & 0.602 & 0.828 & 0.881 \\
\hline
\end{tabular}

Table 2. R-Square Value

\begin{tabular}{lc}
\hline \multicolumn{1}{c}{ Variable } & R-Square \\
\hline Sense of Achievement (X2) & 0.287 \\
Employee's Performance (Y) & 0.543 \\
\hline
\end{tabular}

Table 3. Path Coefficients and T-Statistics Value

\begin{tabular}{|c|c|c|c|c|}
\hline \multicolumn{2}{|c|}{ Hipothesis } & Coefficients & T-Statistics & Notes \\
\hline Y1 & $\begin{array}{c}\text { Leadership (X1) } \rightarrow \\
\text { Sense of Achievement (X2) }\end{array}$ & 0.536 & 5.497 & Significant \\
\hline Y2 & $\begin{array}{c}\text { Leadership (X1) } \rightarrow \\
\text { Employee's Performance (Y) }\end{array}$ & 0.308 & 2.011 & Significant \\
\hline Y3 & $\begin{array}{c}\text { Sense of Achievement (X2) } \rightarrow \\
\text { Employee's Performance (Y) }\end{array}$ & 0.525 & 3.612 & Significant \\
\hline
\end{tabular}

